\title{
Performance improvement and redox cycling of a micro-tubular solid oxide fuel cell with a porous zirconia support
}

\author{
Dhruba Panthi, Bokkyu Choi, Atsushi Tsutsumi* \\ Collaborative Research Center for Energy Engineering, Institute of Industrial Science, The \\ University of Tokyo, 4-6-1 Komaba, Meguro-ku, Tokyo 153-8505, Japan \\ * Corresponding author. Tel.: +81-3-5452-6727; fax: +81-3-5452-6728. \\ E-mail: a-tsu2mi@iis.u-tokyo.ac.jp (A. Tsutsumi)
}

\begin{abstract}
The performance of a novel micro-tubular solid oxide fuel cell (SOFC) with an inert support and an integrated current collector for the inner electrode was improved by controlling its microstructural features. Multi-step dip coating and co-sintering methods were used to fabricate the cell containing porous yttria-stabilized zirconia (YSZ), Ni, Ni-YSZ, YSZ, strontium-doped lanthanum manganite (LSM)-YSZ, and LSM as the inert support, anode current collector, anode, electrolyte, cathode, and cathode current collector, respectively. To enhance gas diffusion through the YSZ support by properly tailoring its porosity, a combination of micro-crystalline cellulose and polymethyl methacrylate pore formers was used. Additionally, the porosity of the Ni current collector was improved and the LSM-YSZ cathode was sufficiently thick for high oxygen reduction activity. Owing to its optimized microstructure, the micro-tubular SOFC delivered excellent power output with maximum power densities of 710, 591, 445, and $316 \mathrm{~mW}$ $\mathrm{cm}^{-2}$ at $850,800,750$, and $700{ }^{\circ} \mathrm{C}$, respectively. The effect of redox cycling on cell performance
\end{abstract}


was investigated by alternately exposing the anode to fuel and air atmospheres. The cell had good tolerance toward the redox phenomenon with no apparent degradation in its performance up to 10 redox cycles.

\section{Keywords}

Micro-tubular SOFC, YSZ support, dip coating, microstructure, porosity, redox cycling 


\section{Introduction}

Fuel cells convert the chemical energy in fuels to electric energy with high efficiency and low emissions. They are expected to play an important role in a low-carbon society. Among the different types of fuel cells, solid oxide fuel cells (SOFCs) are known for their ability to use direct hydrocarbon fuels, simplified fuel processing requirement, and cell components with potentially low-cost and abundant materials [1-4]. Additionally, the high-temperature heat produced by SOFCs makes them attractive candidates for combined-cycle and cogeneration plants [5-7]. The thermo-mechanical properties and power generation characteristics of a SOFC are largely influenced by its geometric design. Comparing the two principal SOFC designs (planar and tubular), the tubular design has competitive advantages such as easy sealing and good thermal-cycling behavior [8,9]. In particular, small-diameter tubular SOFCs, commonly known as micro-tubular SOFCs, have received an increasing amount of attention because of their high volumetric power densities [10-12]. Because the wall thickness of the cell support can be reduced considerably for small-diameter cells without any compromise in mechanical strength, the micro-tubular design offers further desirable properties that consist of high thermal shock resistance and low thermal mass $[10,13]$. These properties, in turn, allow for the rapid startup and shutdown of SOFC stacks.

One of the main challenges associated with existing micro-tubular SOFC designs is their poor current collection efficiency from the inner electrode [14-16]. Current can be tapped from the outer electrode by applying current-collecting materials such as wires or meshes over the whole surface. However, these current-collecting materials cannot be applied over the whole surface of the inner electrode because of the small available bore size. Instead, current has to be tapped 
from the exposed end/s of the inner electrode. This causes a longer current conduction path for the inner electrode, which increases the ohmic resistance. The performance loss because of this kind of ohmic resistance is significant for longer micro-tubular SOFCs with active lengths of more than a few centimeters [14]. To improve the current collection characteristics of microtubular SOFCs, we have proposed a novel micro-tubular SOFC design with an integrated current collecting layer for the inner electrode $[17,18]$. In this design, an inert layer provides structural support to the cell and a thin layer of electrically conducting material on top of the inert layer serves as a current collector for the inner electrode. The thin layer of electrically conducting material can be considered to be identical to a meshed collector with continuous axial contact along the electrode surface, and this is an ideal option for current collection from SOFC electrodes [19]. Simulation studies conducted for micro-tubular SOFCs with an active length of $10 \mathrm{~cm}$ have indicated that because of the lower ohmic overpotential, the proposed design can deliver a distinctly better performance compared with the conventional anode-supported designs [18].

Apart from the current collection characteristics, the stability of micro-tubular SOFCs upon undergoing reduction-oxidation (redox) cycles is also of crucial concern. Among state-of-the-art SOFC anodes, Ni-yttria-stabilized zirconia (YSZ) cermet is the most widely used material. It is prepared by mixing $\mathrm{NiO}$ and $\mathrm{YSZ}$ powders. $\mathrm{NiO}$ in the as-prepared anode is reduced to $\mathrm{Ni}$ under a fuel atmosphere before power generation. The Ni particles may re-oxidize to NiO during the SOFC operation because of several reasons such as seal deterioration, fuel supply interruption, or very high fuel utilization [20]. Owing to the large difference in molar volumes of the two states of $\mathrm{Ni}$ (i.e., $11.198 \mathrm{~cm}^{3} \mathrm{~mol}^{-1}$ for $\mathrm{NiO}$ and $6.589 \mathrm{~cm}^{3} \mathrm{~mol}^{-1}$ for $\mathrm{Ni}$ ), the reduction and oxidation 
processes, respectively, cause significant shrinkage and expansion of the particles. Because $\mathrm{Ni}$ particles do not generally recover to their original states during this redox process, dimensional changes take place in the anode's microstructure [20-23]. These changes give rise to mechanical stresses in the anode as well as the neighboring cell components, which results in the performance degradation of the cell and in the worst case, the structural integrity of the cell may be lost completely [24-26]. In order to improve the redox stability, alternative anode materials such as $(\mathrm{La}, \mathrm{Sr})(\mathrm{Cr}, \mathrm{Mn}) \mathrm{O}_{3}[27]$ and doped $\mathrm{SrTiO}_{3}[28,29]$ have been proposed. However, the performance of these materials in terms of electronic and ionic conductivities, and electrocatalytic activity is still low [30]. Since the Ni-YSZ cermet remains the material of choice for SOFC anodes owing to its electrochemical performance and cost, efforts have been made to improve its dimensional stability under redox conditions via microstructural engineering approaches. One of such approaches is to first prepare a porous YSZ substrate and then introduce Ni particles by infiltration techniques [31-33]. Although the Ni-infiltrated anodes have been found to possess relatively better redox stability, their large-scale production may be timeconsuming and costly [34]. On the other hand, the effect of the redox phenomenon is strongly dependent on the type of the cell support. Performance degradation due to redox cycling is more severe for the widely pursued anode-supported designs because dimensional changes in the thick anode layer can easily affect the thin electrolyte layer [20, 35]. In contrast, the redox-induced mechanical stresses are expected to be very small for the proposed inert support-based microtubular SOFC, which consists of thin anode and anode current collector layers.

In our previous study, a micro-tubular SOFC was successfully fabricated using porous YSZ as the inert support along with $\mathrm{Ni}$, Ni-YSZ, YSZ, strontium-doped lanthanum manganite (LSM)- 
YSZ, and LSM as the anode current collector, anode, electrolyte, cathode, and cathode current collector, respectively [36]. Although the fabricated cell gave good electrochemical performance, a microstructure optimization of the cell components was found to be imperative for a further improvement in its performance. In this work, gas diffusion through the inert support was enhanced using a combination of micro-crystalline cellulose and polymethyl methacrylate (PMMA) pore formers. The micro-crystalline cellulose has already been shown to provide better shrinkage to the support layer at lower sintering temperatures, whereas PMMA beads result in a macroporous (pore size $>50 \mathrm{~nm}$ ) microstructure with well-defined pores. The macroporous microstructure greatly promotes the transport of the reactant and the product gases [37-39]. Additionally, the porosity of the Ni current collector was improved by increasing the amount of the cellulose pore former from 5 to $10 \mathrm{wt} \%$ and the LSM-YSZ cathode was made sufficiently thick for high oxygen reduction activity. The actual effect of redox cycling on the present microtubular SOFC was investigated by alternately supplying humidified $\mathrm{H}_{2}$ and air to the anode. The change in voltage of a single cell at a constant current density was examined after each redox cycle, and scanning electron microscope (SEM) images were used to characterize the microstructural changes caused by redox cycling.

\section{Experimental}

An in-house developed multi-step dip coating method $[36,40]$ was used to fabricate the microtubular SOFC samples. For all the slurries, polyvinyl butyral (PVB; Sigma Aldrich, USA), tallow propylene diamine (Diamin RRT, Kao, Japan) and dioctyl phthalate (DOP; Sigma Aldrich) were used as a binder, dispersant, and plasticizer, respectively. Similarly, a binary mixture of ethanol and toluene was used as the solvent. A YSZ support slurry was prepared by 
mixing YSZ powder (TZ-8Y, Tosoh, Japan) with micro-crystalline cellulose (Avicel, Merck, Germany) and PMMA (2.9 $\mu \mathrm{m}$, Soken Chemical and Engineering, Japan) pore formers in a mass ratio of 8:1:1. After adding the solvent and organic additives, the mixture was ball-milled in a high-density polyethylene (HDPE) container with zirconia grinding media for $24 \mathrm{~h}$. The prepared YSZ slurry was dip coated onto carbon rods $(\varnothing 3 \mathrm{~mm})$ that were cut into the required lengths. The pulling speed for the dip coating was $2 \mathrm{~mm} \mathrm{~s}^{-1}$. The coating process was repeated several times until a desired support layer thickness was achieved. After each dip coating, the samples were placed in an oven at $80{ }^{\circ} \mathrm{C}$ for some time to remove the solvents. On top of the YSZ support, an anode current collector slurry comprising $\mathrm{NiO}$ (NiO-AS, Kceracell, South Korea) and micro-crystalline cellulose (20 $\mu \mathrm{m}$, Sigma Aldrich) in a mass ratio of 9:1 was dip coated. To remove the carbon core and organic materials, the samples were pre-sintered in air at $1000{ }^{\circ} \mathrm{C}$ for $1 \mathrm{~h}$ following a procedure described elsewhere [40].

The pre-sintered $\mathrm{YSZ} / \mathrm{NiO}$ bilayers were dip coated with a NiO-YSZ anode slurry composed of $\mathrm{NiO}$ (NiO-AFL, Kceracell) and YSZ in a mass ratio of 3:2. This was followed by a second presintering at $1000{ }^{\circ} \mathrm{C}$ for $1 \mathrm{~h}$. Subsequently, a YSZ electrolyte slurry was dip coated on top of the $\mathrm{NiO}-\mathrm{YSZ}$ anode layer and the samples were co-sintered in air at $1300^{\circ} \mathrm{C}$ for $3 \mathrm{~h}$. The dip coating method was used again to apply the cathode and cathode current collector layers onto the cosintered half cells. The cathode slurry consisted of LSM (LSM-80F, Daiichi Kigenso Kagaku Kogyo, Japan) and YSZ in a mass ratio of 1:1, whereas the cathode current collector slurry consisted of LSM only. The samples were finally sintered in air at $1150^{\circ} \mathrm{C}$ for $1 \mathrm{~h}$. 
The electrochemical performance of the fabricated micro-tubular SOFCs was measured with an electronic load device (PLZ664WA, Kikusui Electronics Corp., Japan) from $700-850{ }^{\circ} \mathrm{C}$. The SOFC sample was heated in an electric furnace by mounting it on a fuel supply tube with a sealant (Ceramabond 552, Aremco Products, USA). The furnace temperature was first ramped to $850{ }^{\circ} \mathrm{C}$ at a rate of $5{ }^{\circ} \mathrm{C} \min ^{-1}$ and then lowered at a rate of $3{ }^{\circ} \mathrm{C} \min ^{-1}$ for subsequent measurements at lower temperatures. Pt wires were attached with Pt paste to the current collector surfaces and were used as current leads. It is to be noted that current leads containing cheaper materials such as $\mathrm{Ni}$ for the anode and Ag for the cathode may also be used. However, considering the high testing temperatures, at which $\mathrm{Ag}$ is not suitable due to its low melting temperature and high vapor pressure [41], and exposure of the anode current leads to the oxidizing environment in the test setup, Pt was selected for both the anode and cathode current leads. $\mathrm{H}_{2}$ humidified with 3 vol. $\% \mathrm{H}_{2} \mathrm{O}\left(20 \mathrm{~cm}^{3} \mathrm{~min}^{-1}\right)$ and ambient air $\left(20,000 \mathrm{~cm}^{3} \mathrm{~min}^{-1}\right)$ were supplied as the fuel and oxidant gases, respectively. To activate the LSM-YSZ cathode, the cell was discharged at a constant current density of $200 \mathrm{~mA} \mathrm{~cm}^{-2}$ for $2 \mathrm{~h}$ before recording the $I-V$ characteristic curves.

To study the redox stability of the cell, the redox cycling protocol shown in Fig. 1 was used. First, the SOFC sample was heated in air to $800{ }^{\circ} \mathrm{C}$ at a ramp rate of $5{ }^{\circ} \mathrm{C} \mathrm{min}{ }^{-1}$. After the initial reduction of the anode in humidified $\mathrm{H}_{2}$ and the activation of the cathode, the cell voltage was measured at a current density of $400 \mathrm{~mA} \mathrm{~cm}^{-2}$ for $30 \mathrm{~min}$. The $\mathrm{H}_{2}$ supply was then turned off and the anode was exposed to ambient air for 30 min, thus causing the first re-oxidation of Ni (i.e., the first redox cycle). The re-oxidized anode was again exposed to $\mathrm{H}_{2}$ for $30 \mathrm{~min}$ and the cell voltage was measured at the same current density as mentioned above when the cell reached a 
steady-state open-circuit voltage (OCV) value. This was followed by the exposure of the anode to air for another $30 \mathrm{~min}$ to complete the second redox cycle. These procedures were repeated until the completion of the 10th redox cycle. Before each gas change (from $\mathrm{H}_{2}$ to air or from air to $\mathrm{H}_{2}$ ) the anode was purged with $\mathrm{Ar}$ for $2 \mathrm{~min}$.

The cross-sectional microstructures of the SOFC samples were examined using a field emission SEM (SU8000, Hitachi, Japan) equipped with an energy dispersive X-ray (EDX) unit. Archimedes' method was used to measure the open porosity of the YSZ support.

\section{Results and discussion}

A photograph of an as-prepared micro-tubular SOFC sample is shown in Fig. 2. The total length of the cell was $25 \mathrm{~mm}$ and the active cathode length was $8 \mathrm{~mm}$. The inner and outer diameters of the YSZ support tube were ca. 2.4 and $3.5 \mathrm{~mm}$, respectively. Based on a mean electrolyte diameter of $3.6 \mathrm{~mm}$, the active cell area was calculated to be $0.9 \mathrm{~cm}^{2}$.

Figure 3 shows a typical fractured cross-section of the cell before electrochemical testing. The different cell layers were well connected to each other and can be distinguished clearly by the elemental distribution of Ni, Zr, and La. The YSZ electrolyte layer was fully dense and free from cracks or defects. As expected, the NiO-YSZ anode layer was also somewhat dense owing to the absence of a pore former in its slurry. All the other cell components had good porous microstructures. The porosity of the YSZ support and the $\mathrm{NiO}$ anode current collector layers was derived from the pore formers used, whereas that of the LSM-YSZ cathode and the LSM cathode current collector layers was derived from their low sintering temperature. From an EDX line 
scan across the cell cross-section, the thicknesses of the Ni anode current collector, the Ni-YSZ anode, the YSZ electrolyte, the LSM-YSZ cathode, and the LSM cathode current collector layers were estimated to be $16,14,19,22$, and $24 \mu \mathrm{m}$, respectively. It is to be noted that although the thicknesses of the other layers were close to those in our previous work [36], the LSM-YSZ and LSM layers were adjusted to achieve optimum cathode performance [42, 43].

Figure 4(a) shows the microstructure of the YSZ support cross-section and a magnified view of the pores in the same is shown in Fig. 4(b). The microstructure clearly reveals the porosity rendered by the PMMA microspheres. In addition to the large pores formed by the PMMA microspheres, small pores that were formed by microcrystalline cellulose were also observed. The small pores were essential in connecting the large pores and increasing the overall porosity without any adverse effect on the mechanical strength of the YSZ support. Additionally, the use of microcrystalline cellulose as a pore former helped to deliver excellent shrinkage for the YSZ support during co-sintering. Therefore, the electrolyte layer could be densified at $1300{ }^{\circ} \mathrm{C}$. The porosity of the YSZ support was determined to be $43 \%$. This porosity is on the higher side of the desired porosity of a SOFC support [44].

A cross-sectional microstructure of the cell after electrochemical testing is shown in Fig. 5(a). Because the $\mathrm{NiO}$ particles in the anode and the anode current collector layers were reduced to $\mathrm{Ni}$ by the fuel, a clear change in the morphology of these layers can be observed compared with the cell cross-section before electrochemical testing (Fig. 3). As shown in Fig. 5(b), the Ni-YSZ anode had a porous microstructure, and this facilitates the diffusion of fuel gas to the reaction 
sites. The porosity of the Ni current collector layer also increased under the reducing atmosphere, as revealed by the spongy microstructure with fine pores in Fig. 5(c).

Figure 6 shows the $I-V$ performance of the single cell at various temperatures. The OCV of the cell was found to be $1.04 \mathrm{~V}$ (at $850{ }^{\circ} \mathrm{C}$ ) and higher, which further confirmed that the YSZ electrolyte was sufficiently dense to prevent gas crossover. The maximum power densities of the cell were $710,591,445$, and $316 \mathrm{~mW} \mathrm{~cm}^{-2}$ at $850,800,750$, and $700{ }^{\circ} \mathrm{C}$, respectively. These values are $26-35 \%$ higher than the previously reported values [36]. The electrochemical performance of the cell thus increased considerably as a result of the improved microstructure. In addition, the maximum power densities obtained for the present micro-tubular SOFC are competitive with those of conventional anode-supported micro-tubular SOFCs produced using similar materials $[40,45,46]$. This suggests that despite the presence of more cell layers in the inert support-based micro-tubular design, microstructure engineering helps to achieve promising electrochemical performance without incurring additional losses from a gas diffusion or reaction kinetics point of view. Furthermore, as indicated by the simulation results [18], this design could provide better electrochemical performance compared with the conventional designs for cells with longer active lengths. However, further work is necessary to confirm experimentally the competitive advantage of the present design for longer micro-tubular SOFCs. For this, the fabrication of micro-tubular SOFCs with active lengths in the range $5-10 \mathrm{~cm}$ is currently being pursued.

The effect of redox cycling on the cell voltage at $800{ }^{\circ} \mathrm{C}$ under a load current of $400 \mathrm{~mA} \mathrm{~cm}^{-2}$ is shown in Fig. 7. The initial cell voltage was ca. $0.80 \mathrm{~V}$ and this remained nearly constant during 
redox cycling. The sample held in the steady-state test for $2 \mathrm{~h}$ after the 10 th redox cycle had a voltage of ca. $0.79 \mathrm{~V}$. Although the cell voltage for the given load current did not show appreciable change after redox cycling, the OCV of the cell was found to be slightly lower than the initial value of $1.076 \mathrm{~V}$, being $1.016 \mathrm{~V}$ after the $10^{\text {th }}$ redox cycle. The OCV decreased probably because of micro-cracks or pinholes that formed in the electrolyte layer. However, these micro-cracks or pinholes were not revealed by the SEM micrographs, as described subsequently. It is likely that the decrease in the OCV did not affect the cell voltage at $400 \mathrm{~mA}$ $\mathrm{cm}^{-2}$ because of the activation of the LSM-YSZ cathode. It is a well known phenomenon that the performance of LSM-based SOFC cathodes gets improved considerably under cell discharge as a result of the activation of LSM, and this activation may continue for several tens of hours [47, 48]. Thus, the performance enhancement of the LSM-YSZ cathode must have compensated for the OCV drop and maintained the cell output.

Figure 8(a) shows a cross-sectional SEM micrograph of the micro-tubular SOFC after 10 redox cycles. No damage to the electrolyte layer was observed. Additionally, no delamination was evident at the Ni-YSZ anode-YSZ electrolyte and YSZ support-Ni current collector interfaces. Figures 8(b) and (c) show Ni-YSZ anode cross-sections without and with redox-induced microcracks, respectively. In fact, there were only a few locations with the redox-induced micro-cracks and their propagation seemed to be very slow up to the 10th redox cycle. The microstructure of the Ni current collector layer is shown in Fig. 8(d). Although no micro-cracks were present in this layer, the Ni particles were found to be severely agglomerated after redox cycling. As described by Laurencin et al. for electrolyte-supported SOFCs with a thin Ni-YSZ anode [49], it is likely that compressive stress developed in the anode and anode current collector layers during 
redox cycling was accommodated by the formation of micro-cracks and microstructure coarsening, thus preventing cell degradation by delamination or electrolyte cracking. Both the cell voltage measurements and microstructural observations indicate that the effect of redox cycling is much less severe for the presented micro-tubular SOFC design than that for anodesupported designs. In addition to the redox stability, cell performance durability is also an important consideration. The grain growth and coarsening of $\mathrm{Ni}$ particles, in particular, may cause cell performance deterioration during long-term operations. The investigation of this issue will be a subject of our future work.

\section{Conclusions}

The microstructure of a novel micro-tubular SOFC with a porous YSZ support and an integrated $\mathrm{Ni}$ current collector for the Ni-YSZ anode was improved by controlling the porosity and thickness of the cell components. Because of this improved microstructure, the cell performance was found to increase considerably with maximum power densities of $710,591,445$, and 316 $\mathrm{mW} \mathrm{cm} \mathrm{cm}^{-2}$ at $850,800,750$, and $700{ }^{\circ} \mathrm{C}$, respectively. The stability of the cell under redox conditions was investigated by alternately exposing the anode to fuel and air atmospheres. There was only a small decrease in the OCV and the initial cell performance remained nearly constant until the 10th redox cycle. We thus show that the micro-tubular SOFC design presented here can deliver a competitive electrochemical performance along with better redox stability. 


\section{Acknowledgments}

The authors gratefully acknowledge financial support from the Advanced Low Carbon Technology Research and Development Program (ALCA) of the Japan Science and Technology Agency (JST).

\section{References}

[1] Steele BCH, Heinzel A. Materials for fuel-cell technologies. Nature 2001;414:345-52.

[2] Stambouli AB, Traversa E. Solid oxide fuel cells (SOFCs): a review of an environmentally clean and efficient source of energy. Renew Sustain Energy Rev 2002;6:433-55.

[3] Ormerod RM. Solid oxide fuel cells. Chem Soc Rev 2003;32:17-28.

[4] Wachsman ED, Lee KT. Lowering the temperature of solid oxide fuel cells. Science 2011;334:935-9.

[5] Kuchonthara P, Bhattacharya S, Tsutsumi A. Combinations of solid oxide fuel cell and several enhanced gas turbine cycles. J Power Sources 2003;124:65-75.

[6] Kuchonthara P, Bhattacharya S, Tsutsumi A. Combination of thermochemical recuperative coal gasification cycle and fuel cell for power generation. Fuel 2005;84:1019-21.

[7] Zhang X, Chan SH, Li G, Ho HK, Li J, Feng Z. A review of integration strategies for solid oxide fuel cells. J Power Sources 2010;195:685-702.

[8] Singhal SC. Advances in solid oxide fuel cell technology. Solid State Ion 2000;135:305-13.

[9] Sammes NM, Du Y, Bove R. Design and fabrication of a 100W anode supported microtubular SOFC stack. J Power Sources (2005);145:428-34.

[10] Sarkar P, Yamarte L, Rho H, Johanson L. Anode-Supported Tubular Micro-Solid Oxide Fuel Cell. Int J Appl Ceram Technol 2007;4:103-8. 
[11] Howe KS, Thompson GJ, Kendall K. Micro-tubular solid oxide fuel cells and stacks. J Power Sources 2011;196:1677-86.

[12] Lawlor V. Review of the micro-tubular solid oxide fuel cell (Part II: Cell design issues and research activities). J Power Sources 2013;240:421-41.

[13] Roy BR, Sammes NM, Suzuki T, Funahashi Y, Awano M. Mechanical properties of microtubular solid oxide fuel cell anodes. J Power Sources 2009;188:220-4.

[14] Suzuki T, Yamaguchi T, Fujishiro Y, Awano M. Current collecting efficiency of micro tubular SOFCs. J Power Sources 2007;163:737-42.

[15] Virkar AV, Lange FF, Homel MA. A simple analysis of current collection in tubular solid oxide fuel cells. J Power Sources 2010;195:4816-25.

[16] De la Torre R, Avila-Paredes HJ, Sglavo VM. Comparative Performance Analysis of Anode-Supported Micro-Tubular SOFCs with Different Current-Collection Architectures. Fuel Cells 2013;13:729-32.

[17] Panthi D, Choi B, Tsutsumi A. A novel type of micro-tubular SOFC for application in super IGFC system. In: Proc Intl Symp Chem React Eng. Maastricht, NL; 2012.

[18] Panthi D, Tsutsumi A. Development of a High-Performance Micro-Tubular SOFC Based on a Hollow Fiber Support. ECS Trans 2013;57:789-98.

[19] Doraswami U, Droushiotis N, Kelsall GH. Modelling effects of current distributions on performance of micro-tubular hollow fibre solid oxide fuel cells. Electrochim Acta 2010;55:3766-78.

[20] Sarantaridis D, Atkinson A. Redox Cycling of Ni-Based Solid Oxide Fuel Cell Anodes: A Review. Fuel Cells 2007;7:246-58. 
[21] Cassidy M, Lindsay G, Kendall K. The reduction of nickel-zirconia cermet anodes and the effects on supported thin electrolytes. J Power Sources 1996;61:189-92.

[22] Malzbender J, Wessel E, Steinbrech RW. Reduction and re-oxidation of anodes for solid oxide fuel cells. Solid State Ion 2005;176:2201-3.

[23] Ettler M, Blaß G, Menzler, NH. Characterisation of Ni-YSZ-Cermets with Respect to Redox Stability. Fuel Cells 2007;7:349-55.

[24] Waldbillig D, Wood A, Ivey DG. Electrochemical and microstructural characterization of the redox tolerance of solid oxide fuel cell anodes. J Power Sources 2005;145:206-15.

[25] Heo YH, Lee JW, Lee SB, Lim TH, Park SJ, Song RH et al. Redox-induced performance degradation of anode-supported tubular solid oxide fuel cells. Int J Hydrogen Energy 2011;36:797-804.

[26] Monzón H, Laguna-Bercero MA. Redox-cycling studies of anode-supported microtubular solid oxide fuel cells. Int J Hydrogen Energy 2012;37:7262-70.

[27] Shanwen T, Irvine JTS. A redox-stable efficient anode for solid-oxide fuel cells. Nature Mat 2003;2:320-3.

[28] Kolodiazhnyi T, Petric A. The applicability of Sr-deficient n-type $\mathrm{SrTiO}_{3}$ for $\mathrm{SOFC}$ anodes. J Electroceram 2005; 15:5-11.

[29] Li X, Zhao H, Xu N, Zhou X, Zhang C, Chen N. Electrical conduction behavior of La, Co co-doped $\mathrm{SrTiO}_{3}$ perovskite as anode material for solid oxide fuel cells. Int J Hydrogen Energy 2009;34:6407-14.

[30] Cowin PI, Petit CTG, Lan R, Irvine JTS, Tao S. Recent progress in the development of anode materials for solid oxide fuel cells. Adv Energy Mat 2011;1:314-32. 
[31] Busawon AN, Sarantaridis D, Atkinson A. Ni infiltration as a possible solution to the redox problem of SOFC anodes. Electrochem Solid-State Lett 2008;11:B186-9.

[32] Tiwari P, Basu S. Ni infiltrated YSZ anode stabilization by inducing strong metal support interaction between nickel and titania in solid oxide fuel cell under accelerated testing. Int J Hydrogen Energy 2013;38:9494-9.

[33] Hanifi AR, Torabi A, Chen X, Hill S, Sarkar P, Etsell TH. Development of redox resistant fully infiltrated tubular SOFCs. J Electrochem Soc 2014;161:F391-7.

[34] Xiao G, Chen F. Redox stable anodes for solid oxide fuel cells. Front in Energy Res $2014 ; 2: 18$

[35] Zhao K, Kim BH, Xu Q, Ahn BG. Fabrication and characterization of inert-substratesupported tubular single cells by dip-coating process. J Power Sources 2014;245:671-7.

[36] Panthi D, Tsutsumi A. Micro-tubular solid oxide fuel cell based on a porous yttriastabilized zirconia support. Sci Rep 2014;4:5754.

[37] Suzuki T, Hasan Z, Funahashi Y, Yamaguchi T, Fujishiro Y, Awano M. Impact of anode microstructure on solid oxide fuel cells. Science 2009;325:852-5.

[38] Sarikaya A, Petrovsky V, Dogan F. Effect of the anode microstructure on the enhanced performance of solid oxide fuel cells. Int J Hydrogen Energy 2012;37: 11370-7.

[39] Panthi D, Choi B, Tsutsumi, A. Performance enhancement of strontium-doped lanthanum manganite cathode by developing a highly porous microstructure. J Appl Electrochem 2012;42:953-9.

[40] Panthi D, Tsutsumi A. A novel multistep dip-coating method for the fabrication of anodesupported microtubular solid oxide fuel cells. J Solid State Electrochem 2014;18:1899-905. 
[41] Gong Y, Qin C, Huang K. Can Silver Be a Reliable Current Collector for Electrochemical Tests? ECS Electrochem Lett 2013;2:F4-7.

[42] Murray EP, Tsai T, Barnett SA. Oxygen transfer processes in $(\mathrm{La}, \mathrm{Sr}) \mathrm{MnO}_{3} / \mathrm{Y}_{2} \mathrm{O}_{3}$-stabilized $\mathrm{ZrO}_{2}$ cathodes: an impedance spectroscopy study. Solid State Ion 1998;110:235-43.

[43] Kenney B, Karan K. Engineering of microstructure and design of a planar porous composite SOFC cathode: a numerical analysis. Solid State Ion 2007;178:297-306.

[44] Mingyi L, Bo Y, Jingming X, Jing C. Influence of pore formers on physical properties and microstructures of supporting cathodes of solid oxide electrolysis cells. Int J Hydrogen Energy 2010;35:2670-4.

[45] Shikazono N, Sakamoto Y, Yamaguchi Y, Kasagi N. Microstructure and polarization characteristics of anode supported tubular solid oxide fuel cell with co-precipitated and mechanically mixed Ni-YSZ anodes. J Power Sources 2009;193:530-40.

[46] Howe KS, Clark ER, Bowen J, Kendall K. A novel water-based cathode ink formulation. Int J Hydrogen Energy 2013;38:1731-6.

[47] Leng YJ, Chan SH, Khor KA, Jiang SP. Performance evaluation of anode-supported solid oxide fuel cells with thin film YSZ electrolyte. Int J Hydrogen Energy 2004;29:1025-33.

[48] Murakami K, Matsui T, Kikuchi R, Muroyama H, Eguchi K. Activation of LSM Electrode Related to the Potential Oscillation under Cathodic Polarization. J Electrochem Soc 2010;157:B880-4.

[49] Laurencin J, Delette G, Sicardy O, Rosini S, Lefebvre-Joud F. Impact of 'redox' cycles on performances of solid oxide fuel cells: Case of the electrolyte supported cells. J Power Sources 2010;195:2747-53. 


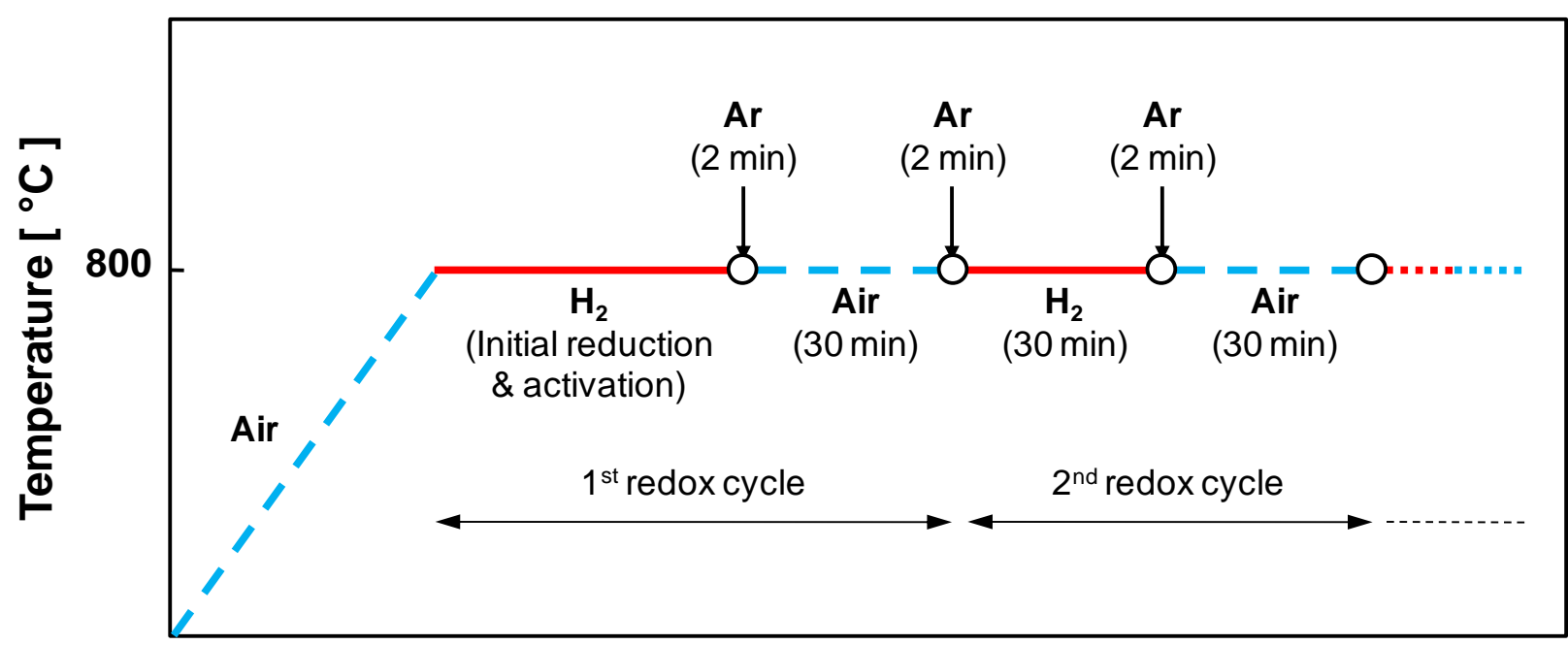

Time

Fig. 1. Redox cycling protocol showing the alternate supply of $\mathrm{H}_{2}$ and air to the anode. 


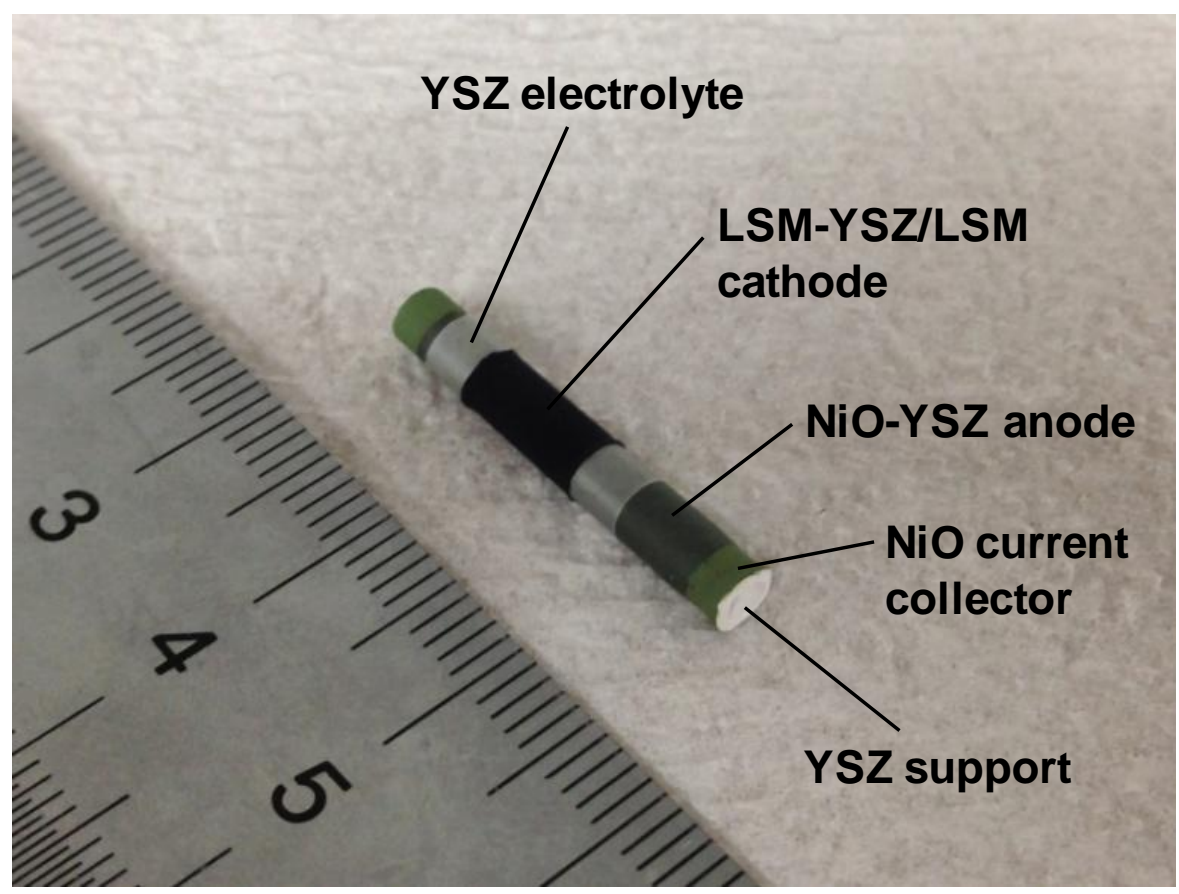

Fig. 2. Photograph of the micro-tubular SOFC. 

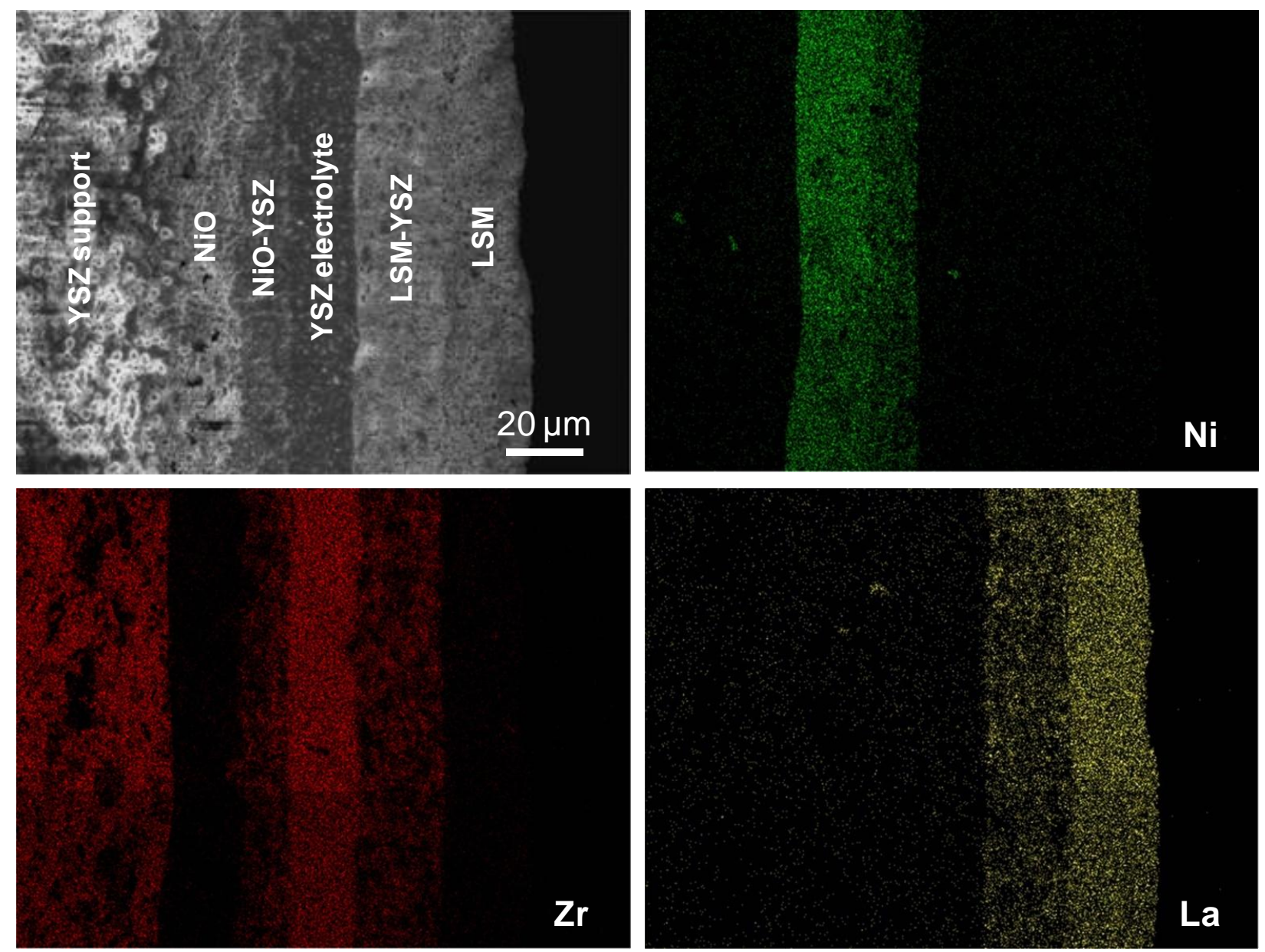

Fig. 3. SEM and EDX micrographs showing the cell cross-section before electrochemical testing with $\mathrm{Ni}, \mathrm{Zr}$ and La elemental mapping. 
(a)

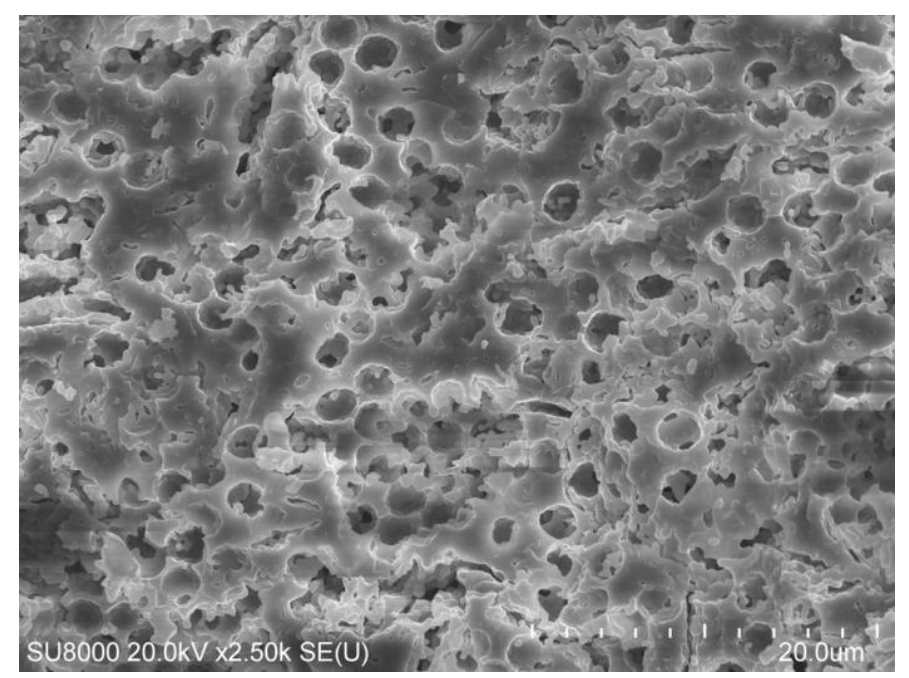

(b)

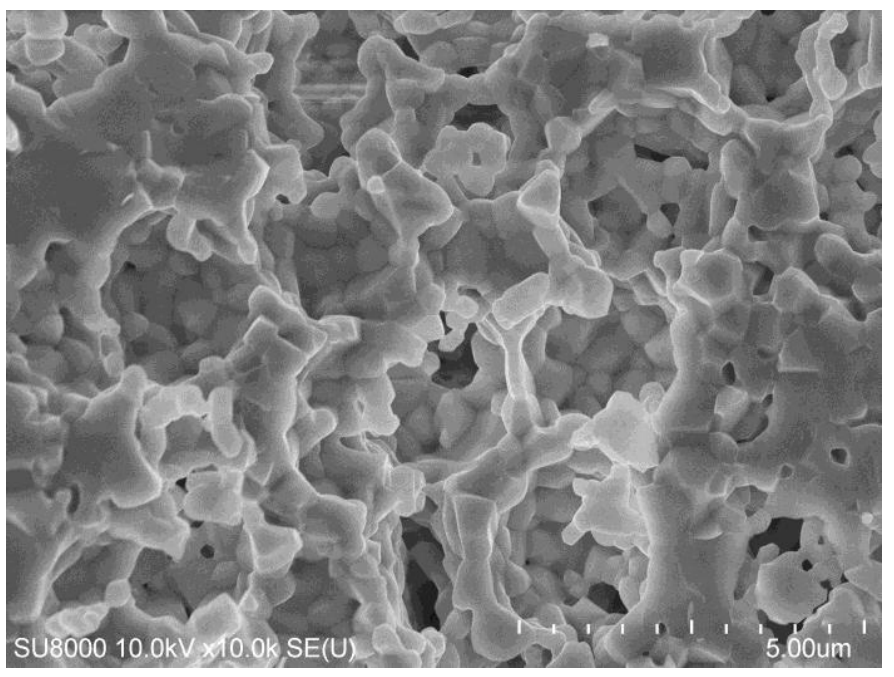

Fig. 4. SEM micrographs: (a) YSZ support cross-section; (b) close-up view of the pores in the YSZ support. 
(a)

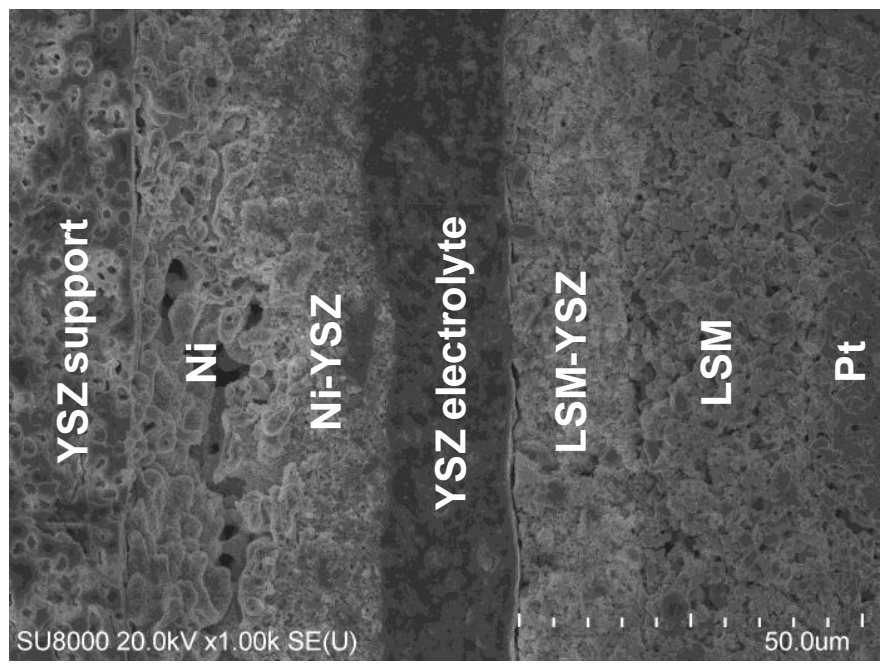

(b)

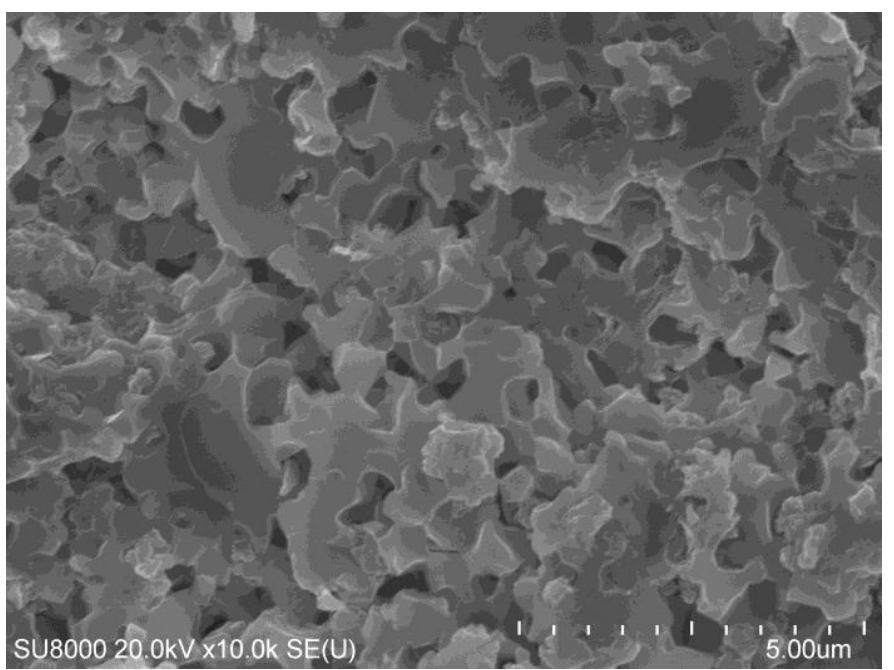

(c)

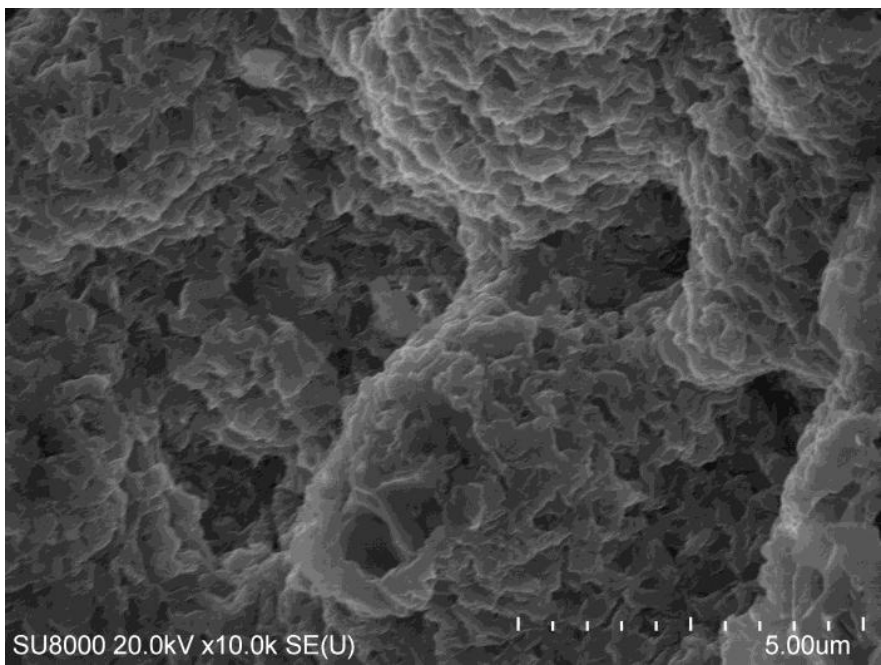

Fig. 5. Cross-sectional SEM micrographs after electrochemical testing: (a) entire cell; (b) NiYSZ anode; (c) Ni current collector. 


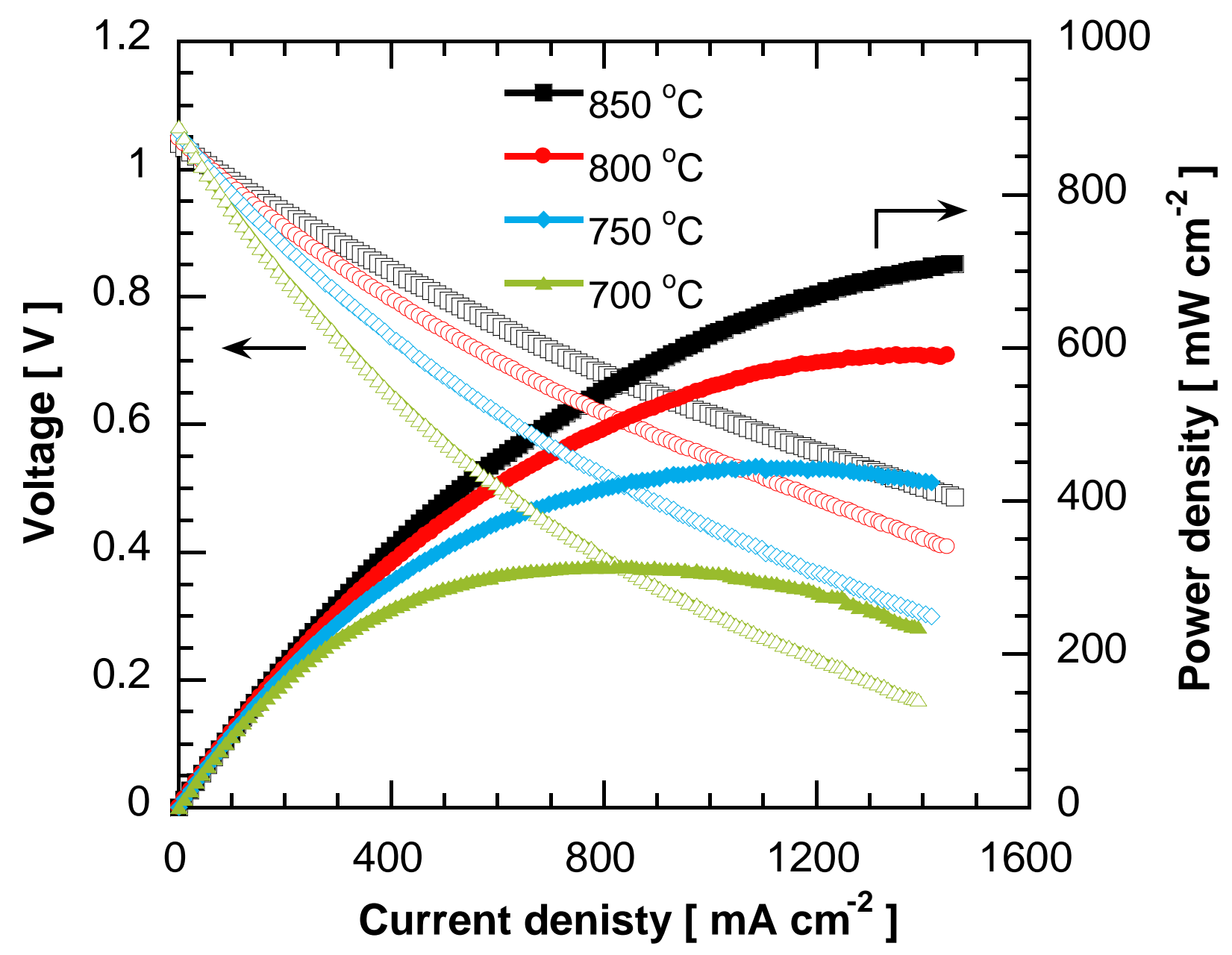

Fig. 6. $I-V$ characteristic curves for the single cell. 


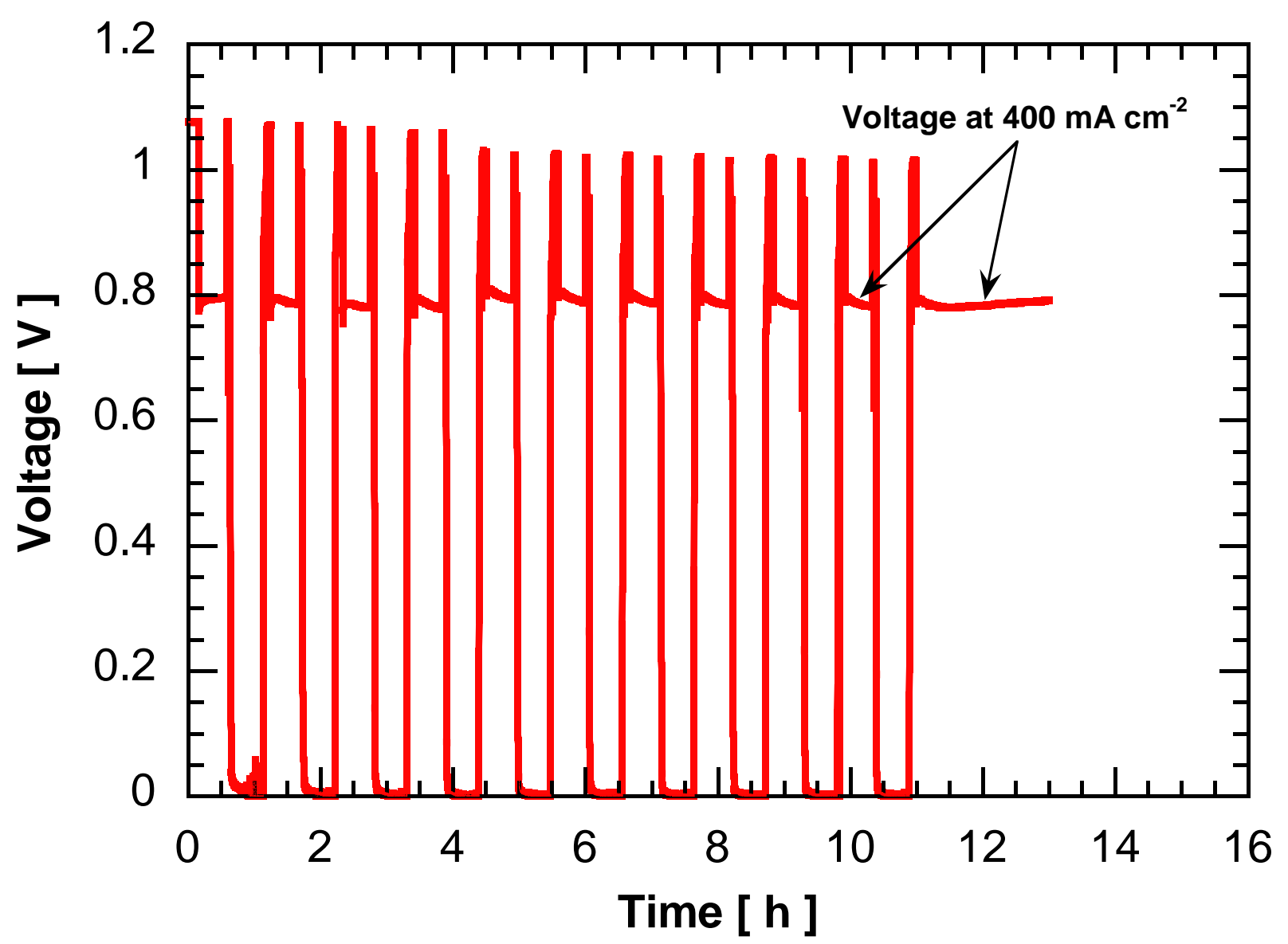

Fig. 7. Variation of OCV and cell voltage at $400 \mathrm{~mA} \mathrm{~cm}^{-2}$ with respect to redox cycling. 
(a)

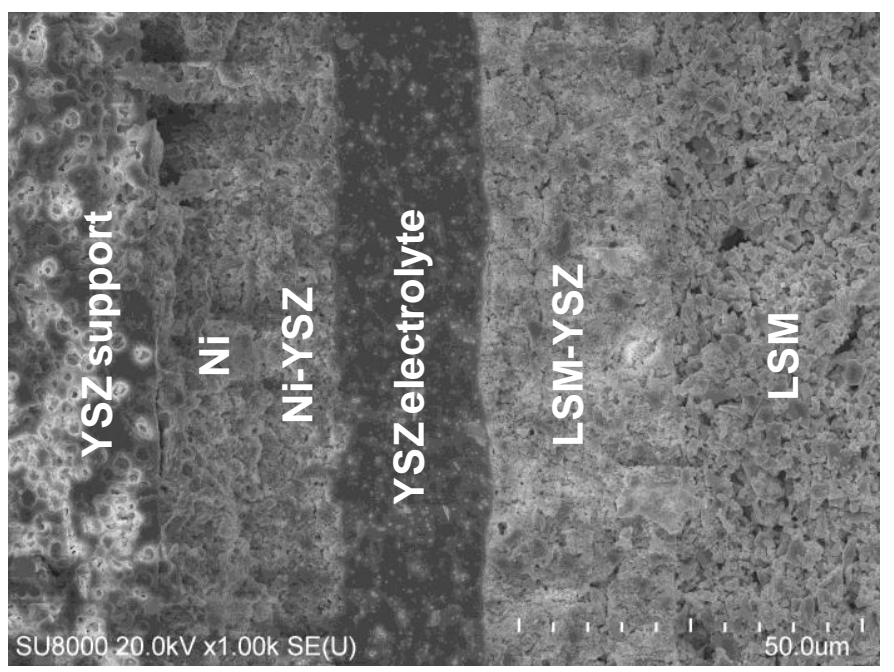

(b)

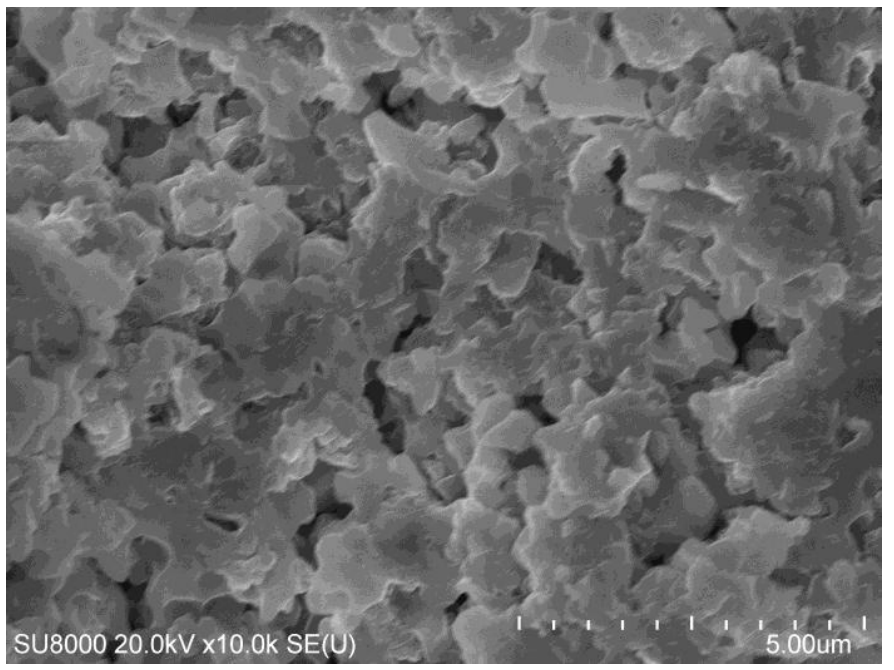


(c)

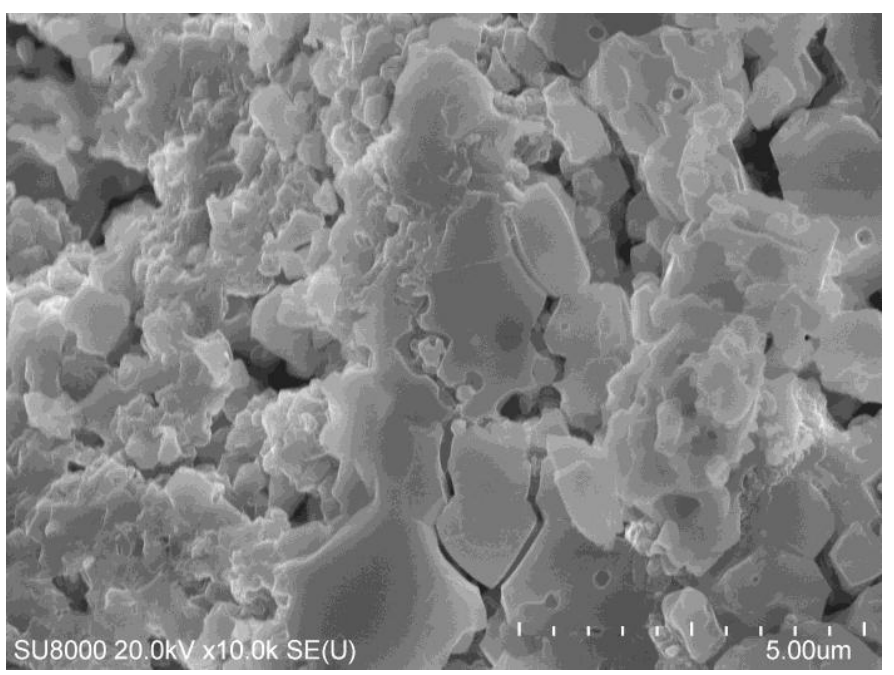

(d)

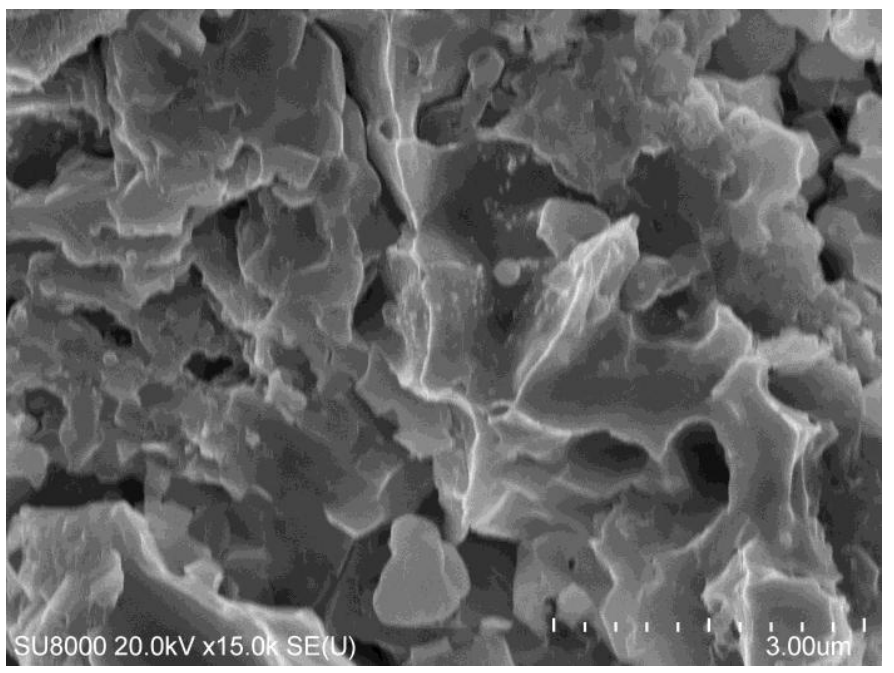

Fig. 8. Cross-sectional SEM micrographs after redox cycling: (a) entire cell; (b) Ni-YSZ anode; (c) redox-induced micro-cracks on Ni-YSZ anode; (d) Ni anode current collector. 